\title{
1. Collective action theory
}

\author{
Robert Holahan and Mark Lubell
}

Collective action dilemmas (hereafter collective dilemmas) occur when the joint decisions of two or more individuals result in socially undesirable outcomes. Collective dilemmas emerge from interdependence - the payoffs to one individual depend on the decisions of others. Solving collective dilemmas requires changing individual decisions through governance arrangements that alter individual payoffs and result in a joint outcome that leaves at least one individual better off without harming any other individuals. Therefore, there is a normative aspect to collective dilemmas, because researchers and practitioners try to find ways to improve social welfare. Some researchers use the term "cooperation" or "coordination" to describe the situation when individuals make decisions that produce more socially desirable outcomes. In game theoretic terms, the goal is often to move from inefficient but stable Nash equilibrium outcomes to mutually beneficial outcomes termed "Pareto-superior." Collective dilemmas are at the heart of most real-world governance challenges, including environmental, health, education, foreign aid, and other policy domains. Hence basic theoretical and empirical research in collective action has important applied implications for the study of governance, and seeks to develop policy recommendations that move toward solutions.

The general definition above applies to many specific types of collective dilemmas. Political economists focus heavily on problems like public goods provision (e.g. Olson [1965] 1971) and common pool resource management (e.g. Ostrom, E. 1990). A number of canonical game theoretical models also represent collective dilemmas (e.g. Axelrod and Hamilton 1981). Field studies and experiments examine attributes of individuals, institutions, and communities that make collective action more or less likely to occur (e.g. Ostrom, E. et al. 1994; Gibson et al. 2005). Social network analysis investigates how the degree of interpersonal connectedness among participants to a collective dilemma affects their ability to solve the dilemma (Lubell et al. 2010).

From the collective action perspective, then, governance attempts to solve these different types of dilemmas by creating institutional arrangements that redefine the payoffs from individual behavior and incentivize cooperation through top-down mandates or encourage bottom-up self-organizing. Governance is a multi-level process that creates monitoring mechanisms, punishes defection, rewards cooperation, provides information, fosters trust-based reciprocity, and otherwise attempts to create the conditions that make collective action likely to occur (Ostrom, E. 2005). Effective governance requires an institutional framework that both positively alters the payoffs to individuals from cooperation and facilitates effective monitoring and enforcement of the rules if and when someone chooses to defect.

Of interest for the current chapter are two collective dilemmas that commonly affect public policy: the efficient production and effective management of public goods and 
common pool resources, respectively. Both types of collective goods share a difficulty in excluding an individual from enjoying their benefits, whether or not the individual contributes to their production or management. Therefore, both types of goods face significant threats from free-riders who can reap benefits without sharing in costs. The goods differ, however, in that common pool resources are rivalrous in consumptionthat is, when an individual consumes a common pool resource, it cannot also be consumed by another individual-while public goods are strictly non-rivalrous in consumption. In the absence of a coordinating governance arrangement, collective goods will be under-provided when private individuals cannot fully capture the positive externalities of provision or over-provided when private individuals cannot fully exclude negative externalities from the exploitation of a common pool resource.

This chapter proceeds as an intellectual history of the transition from attention to how government solves collective dilemmas by establishing top-down institutions to more recent focuses on the provision of collective goods from bottom-up, selfgovernance processes. We begin with the collective dilemmas addressed by classical political philosophers and economists, from Aristotle to Adam Smith. We then discuss early neoclassical economic models, before turning to the institutional solutions to these dilemmas, and then introduce collective dilemmas in complex settings. Finally, we describe how experimental and empirical studies of these collective dilemmas have converged to produce a robust set of findings regarding the likely success (and failure) of alternative governance arrangements in overcoming collective dilemmas.

\section{CLASSICAL THEORIES OF COLLECTIVE ACTION AND GOVERNANCE}

Collective dilemmas are a fundamental aspect of human social life; they have been the focus of a massive literature that spans all social sciences and most biophysical sciences. Though it is impossible to discuss the entirety of historical thought on collective action in the short space available here, it is worth highlighting some of this expansive literature. The manner in which classical philosophers and classical economists envisioned collective dilemmas has had a large impact on the governance arrangements developed by modern societies to provide public goods and successfully manage common pool resources.

Aristotle's (2000) seminal work Politics discusses at length the difficulty in establishing a state that adequately advances the public good. Aristotle argues that Socrates' vision of a democratic state that shares all property in common and holds a unity of purpose is impractical. Instead, Aristotle famously argued that "What is common to the greatest number gets the least amount of care." The collective dilemma envisioned by Aristotle was that of agreeing to a constitution that creates a community, which is necessarily common to all citizens, but in which individuals can still hold private ownership of the household. Though some public goods, such as defense, must be provided by the central state, Aristotle wrote that the self-interest of individuals necessitates that the provisioning of public goods should be limited to those that a central state has a monopoly in providing. 
The collective dilemma inherent in the formation of political order was perhaps the single most important dilemma faced by classical philosophers. Because political order is fundamental for mutually beneficial non-violent exchange, the necessity of a strong central state in providing for political order has been a recurrent theme in political philosophy for centuries. Most famously, Thomas Hobbes wrote of the need for a strong central authority known as the Leviathan to prevent a state of nature "which is called Warre; and such a warre as is of every man, against every man" ([1651] 1968: 185). To Hobbes, humans require a coordinating mechanism to achieve collective action, the benefits of which justify the loss of individual freedoms (even life itself) that are granted to the Leviathan in exchange for political order. Since political order is available to all within a jurisdiction and is non-rivalrous in its use, the Leviathan espoused by Hobbes can be viewed from a contemporary perspective as the manifestation of a system of coercive public goods provision. All political authority flows from the Leviathan down to the citizenry.

Classical economists also touched on the role of central governments in overcoming collective dilemmas. In an often-cited passage from The Wealth of Nations, Adam Smith ([1776] 1981: 723) addressed the problem of providing public goods:

The third and last duty of the sovereign or commonwealth is that of erecting and maintaining those publick institutions and those publick works, which, though they may be in the highest degree advantageous to a great society, are, however, of such a nature, that the profit could never repay the expence to any individual.

To Smith, the proper role of collective goods provisioning extends from the natural status of a state's role as coercive taxer that can overcome the tendency of individuals to free-ride on the contributions of others.

The inquiries into governance pursued by classical philosophers and economists investigated which types of goods are best provided through market mechanisms and which are best provided through coercive government mechanisms. These mechanisms were generally viewed as mutually exclusive. However, this slowly began to change in the nineteenth century as writers began to reflect on the respective roles of central governments and local governments. In essence, writers began to transition from an understanding of government to an understanding of governance. Federalist Paper IX (Hamilton [1787] 1961), for example, discussed at length the need for a central government to coordinate the provision of some public goods like stable political order but also advocated the role of decentralized governance to provide other public goods. Alexis de Tocqueville ([1835] 2000) similarly wrote on the localism of nineteenthcentury America as he witnessed grassroots political organizing across the new nation. In line with the Federalists' belief in the role of decentralized governance, de Tocqueville trumpeted the community-based governance he witnessed, composed of voluntary cooperation and mutual respect. 


\section{NEOCLASSICAL ECONOMIC MODELS OF PUBLIC GOODS AND COMMON POOL RESOURCES}

Among the earliest contemporary models of public goods provision were the economic models developed in the 1950s. These models generally took as given that overcoming the free-rider problem endemic in the provision of collective goods requires a central authority to tax beneficiaries and then directly provide the good. Otherwise, markets could more efficiently provide the goods. Samuelson (1954) explored the nature of collective goods by grouping goods into two categories: private goods are those rivalrous in consumption, and public goods are those non-rivalrous in consumption. While the nature of rivalry implies private goods are most efficiently provided in markets, the externalities associated with the non-rivalry of public goods meant that their efficient provisioning requires a coordinating mechanism (Ostrom, E. 2003). Musgrave (1959) undertook a similar analysis and came to similar conclusions, though he defined the key characteristic separating goods as their relative degree of excludability in consumption. For both models of goods, the ability of free-riders to enjoy the positive externalities in the provision of public goods meant that a government with the ability to coercively tax citizens in exchange for the top-down provisioning of these goods was a natural solution to the dilemma.

Perhaps the most important book written on the topic of collective action in the past 50 years is Mancur Olson's ([1965] 1971) The Logic of Collective Action. Also an economist interested in the provision of public goods, Olson challenged long-held tenets of sociological group theory that assumed rational individuals with a common interest will necessarily act toward that common interest. Instead, Olson asserted that the model of rationality used to derive the prediction of group cooperation also implies that individual rationality will lead to cooperative behavior as an unlikely outcome, rather than an expected one: "Unless the number of individuals in a group is quite small, or unless there is coercion or some other special device to make individuals act in their common interest, rational, self-interested individuals will not act to achieve their common or group interests" ([1965] 1971: 2, italics in original). Though Olson's study was intended to develop a general theory of public goods, much of his analysis actually concerned the management of common pool resources (Ostrom, E. 2003), which were a relatively new area of study at the time of Olson's book.

The beginning of the contemporary study of common pool resources is generally attributed to Gordon (1954), who was interested in understanding the economics of an open access fishery. However, a biologist's essay on "The Tragedy of the Commons" (Hardin 1968) has come to dominate modern policy debates over managing common pool resources. Though the essay primarily concerns implementing coercive measures for population control, Hardin is best remembered for his allegory of two ranchers sharing a pasture in common and each independently deciding on how many cows to graze. Because the benefits of each cow accrue solely to its owner, but the costs of the cow's grazing are shared between the ranchers, each is induced to myopically add cows until the pasture collapses. Similar to the insights of those investigating public goods, Hardin's later (1978) argument was that the open access nature of a common pool resource necessitates governance arrangements in which either the ownership of the 
resource is retained by a central government or the resource is fully privatized by a single owner. Collective action was simply an impossible outcome in Hardin's view.

Samuelson, Musgrave, Olson, and Hardin were each influenced by a model of collective action that assumed the costs of voluntary cooperation are significantly higher than the transaction costs of centralized coordination. This perspective stems from the fact that much of this work also assumes the administrative costs associated with bureaucracy and central organization are negligible, or at least lower than the costs of self-organization (Ostrom, V. 1989). As scholarly understanding of institutions and transaction costs has increased, however, theoretical and empirical studies of collective action no longer make this broad assumption.

\section{NEW INSTITUTIONAL ECONOMICS AND THE POLITICAL ECONOMY OF COLLECTIVE ACTION}

The advent of formal game theory in the 1940s (von Neumann and Morgenstern 1944) marked a transition in economics from a neoclassical view that individually rational action will aggregate into socially optimal payoffs to the view that individually rational action taken within interdependent payoff situations will frequently produce suboptimal social outcomes. The canonical example of this is the Prisoner's Dilemma game, in which two actors following individually rational strategies to defect will earn lower payoffs than if they could be induced to cooperate (Axelrod and Hamilton 1981). Importantly, as noted by E. Ostrom (1990), the logic behind the Prisoner's Dilemma is similar to that of other popular models of interdependent situations, including the Tragedy of the Commons (Hardin 1968) and the Logic of Collective Action (Olson [1965] 1971). While these models of interdependent settings are powerful visualizations of core collective dilemmas, they also came to dominate real-world policy debates over the governance of collective goods before empirical studies had been conducted to evaluate the accuracy of the models (Ostrom, E. 1990). Much of the scholarship on collective goods provision since has been an effort to do just thatempirically ascertain the realism of these early models and, when necessary, to find governance arrangements that overcome their dilemmas.

Chief among the solutions offered by scholars is the development of institutions. Institutions are the rules of the game (North 1990) and include both formal written rules and informal social norms (Ostrom, E. 2005). Actors in interdependent situations operate under a common set of rules and form shared mental models of the choice situation that determines the payoffs from interaction (Aoki 2001). Whether formal or informal, institutions constrain the choice set faced by actors and shift the payoffs such that cooperation can become a dominant strategy. Getting the "institutions right," however, is a continual challenge for policymakers and practitioners. Whether institutions are designed by top-down processes or endogenously emerge through repeated interactions among interdependent actors, the effective governance of collective goods requires the formation of institutions that alter payoffs and incentivize cooperative behavior.

A substantial challenge in formulating effective governance is the ubiquity of transaction costs that actors face (Coase 1960). Transaction costs are the costs 
associated with designing institutions, bargaining over the distribution of resources, monitoring their individual behavior, and enforcing penalties for defection (North 1990). Additionally, transaction costs can take the form of organizational or administrative costs associated with top-down implementation of policy (Williamson 1999). In any given collective dilemma, the costs to self-organize an institutional solution are non-trivial, but so too are the costs of top-down solutions that are imposed onto actors. The extent to which the provision of a collective good is more efficient via a top-down or bottom-up governance arrangement is a function of the relative transaction costs associated with each. Though Coase (1960) was not writing directly to the literature on collective good provisioning contemporaneously being developed, his insights into the nature of transaction costs are fundamental to the study of institutions-as-solutions. Indeed, in a world without transaction costs collective action would not be a dilemma, because it would perfectly and immediately emerge to solve provisioning problems. Because transaction costs are real, however, scholars must take them seriously.

\section{THE PROVISION OF COLLECTIVE GOODS IN COMPLEX SYSTEMS}

Collective goods are provided in complex political-economic systems. In the federal system of the United States, for example, governments composed of overlapping political jurisdictions provide collective goods like policing and sanitation services at multiple levels (i.e. city, county, state) and across geographic boundaries (i.e. water districts, metropolitan areas, neighborhoods) (Ostrom, V. et al. 1961). In self-organized systems of collective good provision, actors create new institutional frameworks within existing higher-level institutional frameworks (Ostrom, E. 2005). In both situations, cooperation is influenced by existing relationships that can either enhance feelings of trust and reciprocity or foment feelings of distrust and apprehension (Lubell et al. 2010). The complexity of the institutional frameworks under which collective goods are provided has been studied extensively from multiple perspectives.

A core dilemma in the provision of collective goods by governments concerns whether political incentives will result in efficient or in sub-optimal levels of the collective goods demanded by citizens. In one school of thought, the overlapping nature of political jurisdictions results in the duplication of services and the over-provision of collective goods (Riker 1964). Similarly, collective goods may be under-produced because each government unit can free-ride on the provision of other government units, producing a collective dilemma within governments. If this is the case, then it provides a justification for the centralization of collective goods provision, as a single government can internalize the externalities of provision and provide at a socially optimal level.

In contrast, proponents of the polycentric theory of governance (McGinnis 1999) argue that government units compete against one another to efficiently provide collective goods and earn tax revenues, which is similar to market competition over private goods (Ostrom, V. et al. 1961). Tiebout (1956) first introduced the concept of competition among multiple governments in the provision of collective goods, arguing that citizens will "vote with their feet" to live in the jurisdiction with the most 
collective goods provisioning relative to the tax rate. These competitive pressures will endogenously result in a socially desirable level of collective goods provision.

Another perspective of governance arrangements that provide collective goods was offered by Buchanan and Tullock (1962). They argued that private clubs permit a small group of individuals to efficiently self-provide some public goods by erecting barriers to free-riders. For example, requiring a toll for use of a road or a membership fee for use of a shared resource could supplant the need for government provision of goods. In a sense, Buchanan and Tullock showed that collective dilemmas can be solved by changing the game being played-in this case from a non-excludable game into one in which partial excludability is possible. Building on this work, V. Ostrom and Ostrom (1977) later introduced a four-goods typology based on both excludability and rivalry that classified goods as private, public, club or common pool resources. By subdividing goods into their component attributes, this work laid the foundation for investigations of increasingly complex settings of collective goods provisioning.

The social-ecological systems (SES) framework provides an example of these complex models. Building on E. Ostrom's (2005) Institutional Analysis and Development framework for analyzing interdependent choice in multi-level institutional settings, the SES framework incorporates biophysical and ecological attributes into a model of collective action (Ostrom, E. 2009). The SES framework incorporates contingent events, like drought or climate change, with analysis of institutions to measure the resilience of existing (or potential) governance arrangements to changing environmental conditions (e.g. Folke et al. 2005). Though still a relatively new area of research, the SES has already developed a large supporting literature (Cox 2014).

While institutions are typically assumed to lower transaction costs and facilitate voluntary cooperation, new insights using the ecology of games (Long 1958) framework have begun to challenge this in complex settings. Lubell et al. (2010), for example, examined transportation and land use planning decisions in California to examine whether interactions within one policy arena influence interactions within another. They demonstrate that, in contrast to conventional wisdom, the experience of actors in one institutional arena can cross over into their interactions in other arenas. Thus, the likelihood of successful collective action often depends on factors not directly related to the specific choice setting; externalities can instead pour over from one setting to another.

\section{EMPIRICS OF COLLECTIVE ACTION: EXPERIMENTS AND FIELD STUDIES}

Theoretical models have shown both the challenges actors face and the benefits from cooperation in interdependent settings. With advancements in experimental economics and field studies, however, scholars have empirically tested the implications of theoretical models. Much of this work has challenged the assumption of a strictly self-interested model of myopic individuals seeking immediate and unilateral gain in favor of a model of group behavior in which voluntary cooperation can endogenously produce successful governance arrangements. As a result, the policy prescriptions arguing that collective goods will only be provided by top-down processes have been 
supplemented by a nuanced theory that allows for both top-down and bottom-up governance arrangements.

While experiments have demonstrated that self-interested individuals exist in most groups, experiments have also found that there are individuals in every group who play strategies that deviate from the self-interest prediction (Fehr and Gaechter 2000). Experiments that model collective dilemmas by giving subjects an endowment and permitting them either to keep it or to voluntarily contribute some of it to the provision of a public good have found that individuals contribute at levels above those predicted by a pure self-interest model (Isaac and Walker 1988). Common pool resource experiments have found the same (Ostrom, E. et al. 1994). Interestingly, these results have held with and without the presence of a sanctioning mechanism.

The impact of other-regarding preferences like trust, reciprocity and altruism has become central to research in collective goods provision. Trust among a community that results in reciprocation for cooperative behavior has been shown to be important for overcoming collective action in field (e.g. Cardenas 2003) and experimental (e.g. Falk and Fischbacher 2006) settings. Preferences for altruism have also been studied extensively (e.g. Andreoni 1989). Interestingly, other-regarding preferences have been shown to be a stable equilibrium of an evolutionary process when selection occurs at the level of a group (Axelrod and Hamilton 1981). Each of these factors influences the ability of individuals in a community to cooperate with one another and develop self-organized governance arrangements that lead to the successful co-management of collective goods provision (Ostrom, E. 1990; Poteete et al. 2010).

E. Ostrom et al. (1992), for example, tested Hobbes's ([1651] 1968) assertion that "Covenants without the sword, are but words," by designing an experimental environment in which some treatments allowed subjects to communicate and utilize costly sanctions. They found that communication, even cheap talk, increases contributions to a collective good independent of sanctions (swords). Subsequent experiments have further demonstrated the positive influence of communication in one-shot (Hackett et al. 1994) and dynamic (Janssen et al. 2010) environments. Field studies have also documented the important role communication plays in voluntary cooperation and have helped to inform a large body of research into other factors that increase the likelihood of voluntary provision of collective goods (Ostrom, E. 1990).

Modern field research on collective goods provision consists of much more than participant observation. Agrawal and Goyal (2001), for example, demonstrated the complex and non-linear relationship between group size and the successful management of shared forest resources. Similarly, the International Forestry Resources and Institutions (IFRI) project measures social and ecological variables in forest-based project sites in over a dozen countries to produce a catalogue of key variables that can be statistically verified as hindering or helping the success of collective action. Analyzing IFRI data, Coleman (2009) showed that the factors most likely to be correlated with healthy forest conditions, such as monitoring and sanctioning institutions, hold regardless of whether the forest is managed by a local community or a central government. While voluntary cooperation can achieve successful management, so too can top-down governance. 


\section{CONCLUSION}

From classical political philosophy to modern experiments and field work, the study of collective action has occupied a central place in scholarly inquiry (Ostrom, E. 1998). Though influential models like the Prisoner's Dilemma and the Tragedy of the Commons portray humans as trapped in a dilemma, unable to successfully provide collective goods, theoretical and empirical developments over the past half century have produced a richer set of conclusions regarding human behavior that allows for the possibility of self-organized and top-down governance solutions and successful cooperation even in the face of non-trivial organizing costs. As E. Ostrom (2007) warned, however, there are no panacea governance arrangements that work at all times in all places. Instead, the challenge remains for policymakers, scholars, and practitioners to explore the relative costs of alternative pathways for collective goods provision and tailor governance arrangements to the characteristics specific to the dilemma.

The future study of collective dilemmas is an exciting field of inquiry. Many of the propositions of earlier theories, such as Olson's ([1965] 1971) group size and group heterogeneity paradox, are ripe for further empirical testing. Recent experimental work (Cason and Gangadharan 2016) demonstrates the potential for expanding on the seminal work of E. Ostrom et al. (1994). The rapid development of the socialecological systems framework (Poteete et al. 2010; Cox 2014) and its future application to the governance of natural resource systems will continue to refine our understanding of the potential for and limits to self-organized resource management. The application of social network analysis (Lubell et al. 2010) to collective dilemmas will allow scholars to further refine theoretical expectations of governance through the application of complex case study analysis. Scholars have produced an impressive body of research into collective dilemmas over the past century, but there remains a great deal of potential to further our understanding of these situations. Students of governance will be at the forefront of these future developments.

\section{REFERENCES}

Agrawal, A. and S. Goyal (2001), 'Group size and collective action: Third-party monitoring in commonpool resources', Comparative Political Studies, 34 (1), 63-93.

Andreoni, J. (1989), 'Giving with impure altruism: Applications to charity and Ricardian equivalence', Journal of Political Economy, 97 (6), 1447-1458.

Aoki, M. (2001), Toward a Comparative Institutional Analysis, Cambridge, MA: MIT Press.

Aristotle (2000), Politics, trans. B. Jowett, Mineola, NY: Dover Thrift.

Axelrod, R. and W.D. Hamilton (1981), 'The evolution of cooperation', Science, 211, 1390-1396.

Buchanan, J. and G. Tullock (1962), The Calculus of Consent: Logical Foundations of Constitutional Democracy, Ann Arbor: University of Michigan Press.

Cardenas, J. (2003), 'Real wealth and experimental cooperation: Experiments in the field lab', Journal of Economic Behavior and Organization, 70 (2), 263-289.

Cason, T.N. and L. Gangadharan (2016), 'Swords without covenants do not lead to self-governance', Journal of Theoretical Politics, 28 (1), 44-73.

Coase, R.H. (1960), 'The problem of social cost', Journal of Law and Economics, 3, 1-44.

Coleman, E. (2009), 'Institutional factors affecting biophysical outcomes in forest management', Journal of Policy Analysis and Management, 28 (1), 122-146. 


\section{Handbook on theories of governance}

Cox, M. (2014), 'Understanding large social-ecological systems: The SESMAD project', International Journal of the Commons, 8 (2), https://www.thecommonsjournal.org/index.php/ijc/article/view/406.

Falk, A. and U. Fischbacher (2006), 'A theory of reciprocity', Games and Economic Behavior, 54 (2), 293-315.

Fehr, E. and S. Gaechter (2000), 'Cooperation and punishment in public goods experiments', American Economic Review, 90 (4), 980-994.

Folke, C., T. Hahn, P. Olsson and J. Norberg (2005), 'Adaptive governance of social-ecological systems', Annual Review of Environmental Resources, 30, 441-473.

Gibson, C.C., K. Andersson, E. Ostrom and S. Shivakurmar (2005), The Samaritan's Dilemma: The Political Economy of Development Aid, New York: Oxford University Press.

Gordon, H.S. (1954), 'The economic theory of a common-property resource: The fishery', Journal of Political Economy, 62 (2), 124-142.

Hackett, S., E. Schlager and J.M. Walker (1994), 'The role of communication in resolving commons dilemmas: Experimental evidence with heterogeneous appropriators', Journal of Environmental Economics and Management, 27 (2), 99-126.

Hamilton, A. ([1787] 1961), 'Federalist IX', in Clinton Rossiter (ed.), The Federalist Papers, New York: New American Library.

Hardin, G. (1968), 'The tragedy of the commons', Science, 162, 1243-1248.

Hardin, G. (1978), 'Political requirements for preserving our common heritage', in H.P. Bokaw (ed.), Wildlife and America, Washington, DC: CEQ, pp. 310-317.

Hobbes, T. ([1651] 1968), The Leviathan, ed. C.B. Macpherson, New York: Penguin Books.

Isaac, R.M. and J.M. Walker (1988), 'Group size effects in public goods provision: The voluntary contribution mechanism', Quarterly Journal of Economics, 103 (1), 179-199.

Janssen, M., R. Holahan, A. Lee and E. Ostrom (2010), 'Sanctioning institutions are not panaceas', Science, 328, 613-617.

Long, N.E. (1958), 'The local community as an ecology of games', American Journal of Sociology, 64 (3), 251-261.

Lubell, M., A.D. Henry and M. McCoy (2010), 'Collaborative institutions in an ecology of games', American Journal of Political Science, 54 (2), 287-300.

McGinnis, M. (1999), Polycentric Governance and Development, Ann Arbor: University of Michigan Press.

Musgrave, R.A. (1959), The Theory of Public Finance, New York: McGraw-Hill.

Neumann, J. von and O. Morgenstern (1944), Theory of Games and Economic Behavior, Princeton, NJ: Princeton University Press.

North, D.C. (1990), Institutions, Institutional Change, and Economic Performance, New York: Cambridge University Press.

Olson, M. ([1965] 1971), The Logic of Collective Action: Public Goods and the Theory of Groups, Cambridge, MA: Harvard University Press.

Ostrom, E. (1990), Governing the Commons: The Evolution of Institutions for Collective Action, New York: Cambridge University Press.

Ostrom, E. (1998), 'A behavioral approach to the rational choice theory of collective action', American Political Science Review, 72 (1), 1-22.

Ostrom, E. (2003), 'How types of goods and property rights jointly affect collective action', Journal of Theoretical Politics, 15 (3), 239-270.

Ostrom, E. (2005), Understanding Institutional Diversity, Princeton, NJ: Princeton University Press.

Ostrom, E. (2007), 'A diagnostic approach for going beyond panaceas', Proceedings of the National Academy of Sciences, 104 (39), 15181-15187.

Ostrom, E. (2009), 'A general framework for analyzing sustainability of social-ecological systems', Science, 325, 419-422.

Ostrom, E., J.M. Walker and R. Gardner (1992), 'Covenants with and without a sword: Self-governance is possible', American Political Science Review, 86 (2), 404-417.

Ostrom, E., R. Gardner and J.M. Walker (1994), Rules, Games, and Common-pool Resources, Ann Arbor: University of Michigan Press.

Ostrom, V. (1989), The Intellectual Crisis in American Public Administration, 2nd edn, Tuscaloosa: University of Alabama Press.

Ostrom, V. and E. Ostrom (1977), 'Public goods and public choices', in E.S. Savas (ed.), Alternatives for Delivering Public Services: Toward Improved Performance, Boulder, CO: Westview Press.

Ostrom, V., C. Tiebout and R. Warren (1961), 'The organization of government in metropolitan areas: A theoretical inquiry', American Political Science Review, 55 (4), 831-842. 
Poteete, A., M. Janssen and E. Ostrom (2010), Working Together: Collective Action, the Commons, and Multiple Methods in Practice, Princeton, NJ: Princeton University Press.

Riker, W.H. (1964), Federalism: Origin, Operation, Significance, Boston, MA: Brown \& Co.

Samuelson, P. (1954), 'The pure theory of public expenditure', Review of Economics and Statistics, 36 (4), 387-389.

Smith, A. ([1776] 1981), An Inquiry into the Nature and Causes of the Wealth of Nations, Indianapolis, IN: Liberty Fund.

Tiebout, C. (1956), 'A pure theory of local expenditures', Journal of Political Economy, 64 (5), $416-424$.

Tocqueville, A. de ([1835] 2000), Democracy in America, trans. Henrey Reeve, New York: Bantam.

Williamson, O. (1999), 'Public and private bureaucracies: A transaction cost economics perspective', Journal of Law, Economics, and Organization, 15 (1), 306-342. 